\title{
INHIBITORS OF POLYPEPTIDE ELONGATION ON YEAST POLYSOMES
}

\author{
M. Barbacid, M. Fresno and D. Vazquez* \\ Instituto de Biologia Celular, Velazquez 144, Madrid 6, Spain \\ (Received for publication February 22, 1975)
}

\begin{abstract}
Yeast polysomes are very active for amino acid incorporation when supplemented with elongation factors and the different components required for elongation of the polypeptide chain. This polysomal system is suitable for the study of the individual steps of the elongation cycle and to test the effect of different inhibitors. Anisomycin, trichodermin, trichodermol, trichothecin, fusarenon $\mathrm{X}$, sparsomycin and blasticidin $\mathrm{S}$ inhibit peptide bond formation on these polysomes, whereas diphtheria toxin, pederine, cycloheximide and cryptopleurine block translocation.
\end{abstract}

Most of the components required for protein synthesis have been obtained in a highly purified form. This has led to sophisticated assays and model systems to study the mechanism of action of inhibitors of protein synthesis. However, the results with such systems do not always agree with those obtained in vivo or in vitro using less resolved systems ${ }^{1 \text {; review). In order }}$ to have a natural in vitro system we have prepared highly purified yeast polysomes which are very active for polypeptide synthesis in the presence of a supernatant fraction containing the elongation factors. Using these polysomes we have studied (a) amino acid incorporation, as an assay for polypeptide elongation, and (b) the puromycin reaction, adding this antibiotic either, before or after the supernatant fraction, to assay peptide bond formation and translocation. The results obtained are presented in this work.

\section{Meterials and Methods}

Yeast polysomes from Saccharomyces cerevisiae strain A224A were prepared following basically methods already described ${ }^{2,3)}$. For polysome purification from free ribosomes, the S-10 extract was placed on a discontinuous gradient made with $20 \%(6 \mathrm{ml})$ and $60 \%(10 \mathrm{ml})$ sucrose in $20 \mathrm{~mm}$ Tris- $\mathrm{HCl}$ buffer, $\mathrm{pH} 7.4$, containing $30 \mathrm{mM} \mathrm{MgCl}_{2}$ and $100 \mathrm{mM} \mathrm{KCl}$. Centrifugation was carried out at $175,000 \mathrm{~g}$ for 1 hour. The pellet and the $7 \mathrm{ml}$ in the lower part of the tube were taken out, diluted with buffer, placed on a $60 \%$ sucrose layer and centrifuged at 70,000 $\mathrm{g}$ for 12 hours to sediment the polysomes. The pellet was resuspended and clarified and this polysome preparation was kept in small aliquots under liquid nitrogen. Two-litre volumes of yeast culture were grown up to an $\mathrm{A}_{660}$ absorbance of 0.36 units for a single polysome preparation. The S-10 supernatant fraction containing the elongation factors was obtained as previously described ${ }^{3)}$. The polysome preparation was totally inactive for amino acid incorporation in the absence of the S-10 supernatant fraction.

Peptidyl- $\left[{ }^{3} \mathrm{H}\right]$ puromycin synthesis was carried out in $0.05 \mathrm{ml}$ volumes of reaction mixtures containing $50 \mathrm{~mm}$ Tris- $\mathrm{HCl}$ buffer, $\mathrm{pH} 7.4,12.5 \mathrm{mM} \mathrm{MgCl}_{2}, \mathrm{KCl}$ as specified in each experiment, $2.3 \mathrm{~A}_{280}$ units of polysomes and $4 \mu \mathrm{M}\left[{ }^{3} \mathrm{H}\right]$ puromycin (The Radiochemical Centre, Amersham, $3.7 \mathrm{Ci} / \mathrm{mmol}$ ). The reaction mixture was incubated for 1 minute for the puromycin reaction to take place. The reaction was stopped by addition of $1 \mathrm{ml}$ of $10 \%$ trichloroacetic acid. Samples were filtered as described ${ }^{4)}$ using GF/C glass fibre Whatman filters. Blanks were obtained by

* To whom requests for reprints should be addressed. 
addition of trichloroacetic acid before $\left[{ }^{3} \mathrm{H}\right]$ puromycin, and the values obtained were subtracted in all cases. When peptidyl-tRNA translocation was desired the reaction mixtures were preincubated at $30^{\circ} \mathrm{C}$ for 7 minutes with $0.5 \mathrm{~mm}$ GTP and $5 \mu \mathrm{l}$ crude supernatant fraction prior to the addition of $\left[{ }^{3} \mathrm{H}\right]$ puromycin.

Fig. 1. Time course of $\left\{{ }^{14} \mathrm{C}\right\}$ phenylalanine incorporation by yeast polysomes

Standard reaction mixtures of $50 \mu \mathrm{l}$ volumes contained: $50 \mathrm{~mm}$ Tris- $\mathrm{HCl}$ buffer, $\mathrm{pH} 7.4,12.5$ $\mathrm{mm} \mathrm{MgCl}_{2}, 80 \mathrm{~mm} \mathrm{KCl}, 1 \mathrm{~mm}$ dithiotreitol, $1 \mathrm{~mm}$ ATP, $0.08 \mathrm{~mm}$ GTP, $4 \mathrm{~mm}$ creatine phosphate, $40 \mu \mathrm{g} / \mathrm{ml}$ creatine phosphokinase, $40 \mu \mathrm{g} / \mathrm{ml}$ yeast tRNA, $0.02 \mathrm{~mm}$ of 19 non radioactive aminoacids (phenylalanine was omitted), $0.015 \mathrm{~mm}\left[{ }^{14} \mathrm{C}\right]$ phenylalanine $(180 \mathrm{mCi} / \mathrm{mmol}), 5 \mu \mathrm{l}$ of crude supernatant fraction and $0.7 \mathrm{~A}_{2 B 0}$ units of polysomes.

The reaction, started by addition of the polysomes, was carried out at $30^{\circ} \mathrm{C}$ for the required time and stopped with $1 \mathrm{ml}$ of $10 \%$ cold trichloroacetic acid. Samples were filtered through $\mathrm{GF} / \mathrm{C}$ glass fiber Whatman filters, washed with $5 \%$ cold trichloroacetic acid, dried and counted in a liquid scintillation spectrometer.

In a parallel experiment $2 \times 250 \mu 1$ samples were prepared as described above.

One of these samples was layered on the top of a $15 \sim 30 \%$ linear sucrose gradient in $50 \mathrm{~mm}$ Tris- $\mathrm{HCl}$ buffer, $\mathrm{pH} 7.4,30 \mathrm{~mm}^{\circ} \mathrm{MgCl}_{2}$ and 100 $\mathrm{mm} \mathrm{KCl}$. The other $250 \mu \mathrm{l}$ sample was incubated for 1 hour at $30^{\circ} \mathrm{C}$ and then layered on identical gradients. Both gradients were centrifuged for 30 minutes at $45,000 \mathrm{rpm}$ in a SW50.1 Spinco/Beckman rotor. Profiles showing the decay of polysomes were monitored in an Isco gradient analyzer and are presented in the figure.

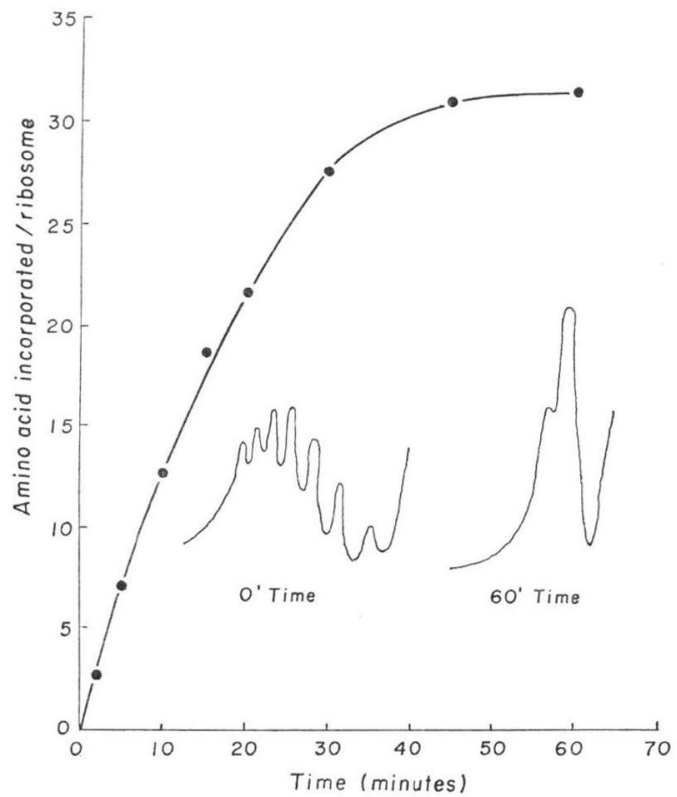

Binding assays of $\left[{ }^{3} \mathrm{H}\right]$ anisomycin $(260$ $\mathrm{mCi} / \mathrm{mmol})^{5)}$ were carried out as previously descrided $^{6)}$. Sources of the different protein synthesis inhibitors were as indicated elsewhere ${ }^{7,8)}$.

\section{Results}

\section{Amino Acid Incorporation Activity of Yeast Polysomes}

The yeast polysome preparation incorporated amino acids into trichloroacetic acid insoluble material; an average of $30 \sim 35$ amino acids were incorporated per monoribosome unit for a period of 45 minutes incubation at $30^{\circ} \mathrm{C}$ (Fig. 1). The reaction was linear, at least for 15 minutes. The decay of the polysome profile was followed in a parallel experiment in which formation of run-off monosomes from polysomes was observed although it was not completed (Fig. 1). The system requires GTP and is dependent on the addition of the total amino acid mixture. When $\left[{ }^{14} \mathrm{C}\right]$ phenylalanine was the only amino acid added to the reaction mixture, incorporation of radioactivity was reduced about 40 times.

Effect of Protein Synthesis Inhibitors on Amino Acid Incorporation by Yeast Ribosomes

A number of inhibitors were tested in the system described above to measure their effect on the elongation cycle; the antibiotics were added at the beginning of the incubation. The results obtained are presented in Table 1 . Tenuazonic acid has no effect since it specifically inhibits protein synthesis by mammalian systems ${ }^{9)}$. High concentrations of actinobolin, amicetin and showdomycin are required to inhibit amino acid incorporation by yeast ribosomes (resultes not shown) as observed in other eukaryotic system for translation ${ }^{8,10-13)}$. 
Table 1. Effect of inhibitors on the elongation cycle of yeast protein synthesis

\begin{tabular}{l|c|c}
\hline \multicolumn{1}{c|}{ Inhibitor } & mM conc. & $\begin{array}{c}{ }^{14} \text { C]Phenylalanine } \\
\text { incorporation } \\
\% \text { Control }\end{array}$ \\
\cline { 2 - 3 } Anisomycin & 0.1 & 6 \\
Tenuazonic acid & 1 & 100 \\
Sesquiterpene antibiotics: & 0.1 & 52 \\
$\quad$ Trichodermin & 0.1 & 68 \\
$\quad$ Trichodermol & 0.1 & 10 \\
$\quad$ Trichothecin & 0.1 & 1 \\
$\quad$ Fusarenon X & 0.01 & 1 \\
Sparsomycin & 1 & 12 \\
Blasticidin S & 1 & 35 \\
Gougerotin & 1 & 76 \\
Actinobolin & 0.1 & 2 \\
Puromycin & 0.1 & 0 \\
Diphtheria toxin & 0.1 & 23 \\
Pederine & 1 & 26 \\
Cycloheximide & 1 & 50 \\
Streptovitacin A & 0.01 & 8 \\
Cryptopleurine & 1 & 10 \\
Emetine & 0.2 & 21 \\
Doxycycline & &
\end{tabular}

The reaction mixture was prepared as described under the legend of Fig. 1 but the required inhibitor was added. Reaction was initiated with polysomes. Incubation took place for 30 minutes at $30^{\circ} \mathrm{C}$ and was stopped by the addition of $1 \mathrm{ml}$ of $10 \%$ cold trichloroacetic acid. Incorporation in the control was 24 pmoles of $\left[{ }^{14} \mathrm{C}\right]$ phenylalanine which corresponded approximately to an average of 33 amino acid residues per monosome unit. Blanks (obtained by adding the trichloroacetic acid before polysomes), were subtracted in all cases. NAD $(0.01 \mathrm{~mm})$ was present in the system when the effect of diphtheria toxin was assayed.

Characteristics of the Puromycin and the Translocation Reactions by Yeast Polysomes

PESTKA et $a l^{4)}$ have reported the requirement of a very high concentration of $\mathrm{K}^{+}(0.8 \sim 1.0 \mathrm{M})$ for the optimal activity of the puromycin reaction on rat liver and brain polysomes. We have indeed confirmed these results in our polysomal system from yeast (Fig. 2). Cycloheximide behaves as an inhibitor of peptide bond formation only under these ionic conditions but not at more physiological $\mathrm{K}^{+}$concentrations (Table 2)'; review. Furthermore, enzymic translocation only occurs at $\mathrm{KCl}$ concentrations lower than $400 \mathrm{~mm}$ (Fig. 2), and by following the kinetics of the puromycin reaction we observed that even at the plateau only $60 \%$ of the peptidyl-tRNA reacting at $0.8 \mathrm{M} \mathrm{KCl}$ would react at $0.2 \mathrm{M} \mathrm{KCl} \mathrm{(Fig.} \mathrm{3).} \mathrm{These} \mathrm{results} \mathrm{agree} \mathrm{with} \mathrm{those}$ previously obtained by other workers suggesting that some peptidyl-tRNA which under physiological conditions is bound to the ribosome in a position not reactive with puromycin, is positioned in the reactive site at the higher $\mathrm{K}^{+}$or $\mathrm{NH}_{4}{ }^{+}$concentrations ${ }^{16,17}$. Variations of $\mathrm{Mg}^{++}$ concentrations from 5 to $25 \mathrm{~mm}$, did not affect the reaction. Therefore we have studied the puromycin and the translocation reactions under the same ionic conditions described for amino acid incorporation. 
The kinetics of the puromycin reaction in the presence and in the absence of a supernatant fraction containing the elongation factors are shown in Fig. 4. The ratio between both kinetics (continuous line in Fig. 4) gives the percentage of peptidyl-tRNA bound to the P-site. This

Fig. 2. Effect of $\mathrm{KCl}$ concentration on the translocation of peptidyl-tRNA

Reaction mixtures of $50 \mu \mathrm{l}$ volumes contained: $50 \mathrm{~mm}$ Tris- $\mathrm{HCl}$ buffer, pH 7.4, $12.5 \mathrm{~mm} \mathrm{MgCl}_{2}$, $2.3 \mathrm{~A}_{260}$ units of polysomes and the required $\mathrm{KCl}$ concentration. Samples were incubated for 7 minutes at $30^{\circ} \mathrm{C},\left[{ }^{3} \mathrm{H}\right]$ puromycin $(3.7$ $\mathrm{Ci} / \mathrm{mmol}$ ) was then added and incubation proceeded for 1 minute more. Reaction was stopped with $1 \mathrm{ml}$ of $10 \%$ cold trichoroacetic acid. The amount of peptidyl- $\left[{ }^{3} \mathrm{H}\right]$ puromycin formed was determined according to PESTKA et $\left.a l^{4}\right)$ using GF/C glass fiber Whatman filters.

(A) Peptidyl- $\left[{ }^{3} \mathrm{H}\right]$ puromycin formation in the control without GTP and supernatant fraction; (B) peptidyl-[ $\left[{ }^{3} \mathrm{H}\right]$ puromycin formation when 0.5 MM GTP and $5 \mu 1$ of the crude supernatant fraction were added to the initial reaction mixture to translocate peptidyl-tRNA.

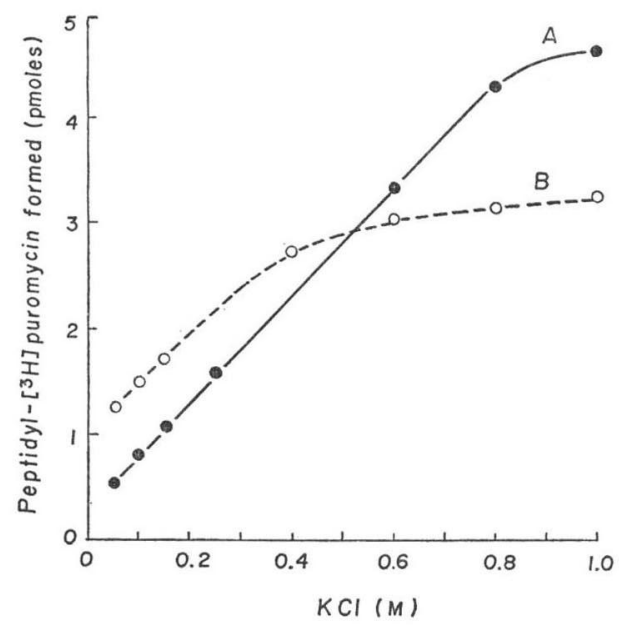

Fig. 3. Time course of peptidy $1-\left[{ }^{3} \mathrm{H}\right]$ puromycin formation by yeast polysomes

Effect of $\mathrm{KCl}$ concentration. Reaction mixtures of $50 \mu \mathrm{l}$ volumes contained: $50 \mathrm{~mm}$ Tris$\mathrm{HCl}$ buffer, $\mathrm{pH} 7.4,12.5 \mathrm{mM} \mathrm{MgCl}_{2}, 4 \mu \mathrm{M}\left[{ }^{3} \mathrm{H}\right]-$ puromycin, $2.3 \mathrm{~A}_{2 e 0}$ units of polysomes and either $200 \mathrm{~mm} \mathrm{KCl}$ or $800 \mathrm{~mm} \mathrm{KCl}$.

The reaction was initiated by addition of the polysomes, incubation took place at $30^{\circ} \mathrm{C}$ for the required time and was stopped with $1 \mathrm{ml}$ of $10 \%$ cold trichloroacetic acid.

Samples were treated as described in legend of Fig. 2 .

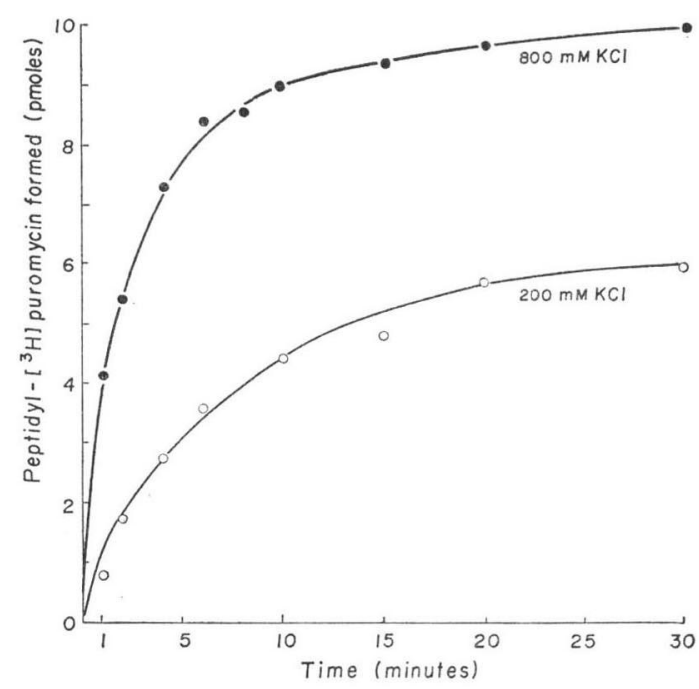

Table 2. The effect of potassium concentration on the inhibition of peptidyl-[ $\mathrm{H} H]$ puromycin formation by cycloheximide

\begin{tabular}{|c|c|c|c|}
\hline Conditions & $\mathrm{KCl}$ (mM conc.) & $\begin{array}{l}\text { Peptidyl- }\left[{ }^{3} \mathrm{H}\right] \text { puromycin } \\
\text { pmoles synthesized/min }\end{array}$ & $\%$ Inhibition \\
\hline Control & 800 & 4.32 & - \\
\hline +Cycloheximide $1 \mathrm{~mm}$ & 800 & 0.74 & 83 \\
\hline Control & 200 & 1.28 & - \\
\hline +Cycloheximide $1 \mathrm{~mm}$ & 200 & 0.63 & 52 \\
\hline Control & 80 & 0.71 & - \\
\hline +Cycloheximide $1 \mathrm{~mm}$ & 80 & 0.60 & 16 \\
\hline
\end{tabular}

Reaction mixtures of $50 \mu \mathrm{l}$ volumes contained: $50 \mathrm{~mm}$ Tris- $\mathrm{HCl}$ buffer, $\mathrm{pH} 7.4,12.5 \mathrm{mM} \mathrm{MgCl}_{2}, 4 \mu \mathrm{M}$ $\left[{ }^{3} \mathrm{H}\right]$ puromycin $(3.7 \mathrm{mCi} / \mathrm{mmol})$ and the required $\mathrm{KCl}$ concentration. The reaction $\left(1 \mathrm{minute}\right.$ at $\left.30^{\circ} \mathrm{C}\right)$ was initiated by adding $2.3 \mathrm{~A}_{280}$ units of polysome. The incubation was stopped with trichloroacetic acid and the peptidyl-[ $\left.{ }^{3} \mathrm{H}\right]$ puromycin reacted determined as described under Materials and Methods in Fig. 2. 
ratio was time dependent, suggesting that there is a slow translocation even in the absence of $\mathrm{K}^{+}$. However, when the puromycin reaction was carried out for short incubation times (1 minute) $55 \sim 60 \%$ of the peptidyltRNA bound remains still attached to the A-site and is sufficient to measure the supernatant fraction-dependent translocation.

\section{Localization of the Peptidyl-tRNA in Yeast Polysome Preparations}

We have recently shown that different polysomal structures of the elongation cycle can be detected by $\left[{ }^{3} \mathrm{H}\right]$ anisomycin binding studies $^{18)}$. The affinity of the interaction of this labelled antibiotic with polysomes is 15 times higher when carrying the peptidyl-tRNA bound to the P-site (post-translocated polysomes) than when the peptidyl-tRNA is bound to the A-site (pre-translocated polysomes). We studied $\left[{ }^{3} \mathrm{H}\right]$ anisomycin binding to polysomes that had been frozen in vivo with 0.03 mM cycloheximide, to determine the percentage of polysomes with peptidyl-tRNA in the Por in the A-site. We found that only $12 \%$ of the cycloheximide blocked polysomes bind $\left[{ }^{3} \mathrm{H}\right]$ anisomycin with strong affinity, wherease abount $76 \%$ bind $\left[{ }^{3} \mathrm{H}\right]$ anisomycin with low
Fig. 4. Time course of peptidyl- $\left[{ }^{3} \mathrm{H}\right]$ puromycin formation by pre- and post-translocated polysomes

A reaction mixture which was prepared as described in Fig. 2, but in the presence of 80 $\mathrm{mm} \mathrm{KCl}$ was incubated for the required times. (A) Peptidyl- $\left[{ }^{3} \mathrm{H}\right]$ puromycin formation by polysomes with peptidyl-tRNA translocated by incubation with GTP and crude supernatant fraction; (B) peptidyl- $\left[{ }^{3} \mathrm{H}\right]$ puromycin formation by control non-translocated polysomes without GTP and supernatant fraction. The ratio between both curves (C) showed the percentage of the peptidyl-tRNA bound to the P-site in the non translocated polysomes.

For times shorter than 1 minute the extrapolation plot (dotted line) is presented. This shows that at time 0 , about $16 \%$ of the total polysomes have the peptidyl-tRNA bound to the P-site.

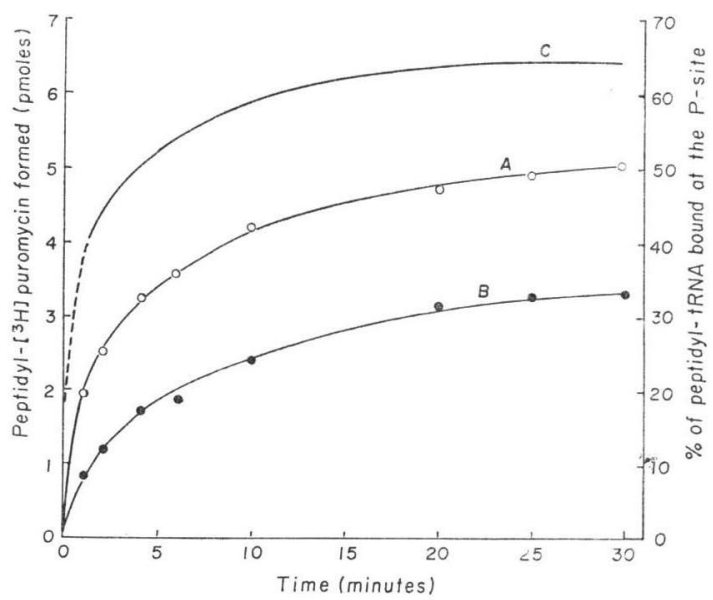
affinity. Therefore most of the polysomes must be in a pre-translocated state (Fig. 5). This is supported by kinetic consideration of the results presented in Fig. 4 on extrapolation to 0 minute of incubation (16\% of peptidyl-tRNA bound at the P-site). Furthermore, results shown in Figs. 4 and 5 agree with other reports showing that in polysomes frozen in vivo with cycloheximide most of the peptidyl-tRNA was associated with the ribosomal A-site ${ }^{10,20)}$.

\section{Effects of Inhibitors on Peptide Bond Formation}

To test specifically the effect of the inhibitors on peptide bond formation, the polysomes were preincubated in the presence of GTP and the supernatant fraction to translocate the peptidyl-tRNA in the absence of any inhibitor, and different conditions were then followed in Assays A and B (Table 3). In Assay A the required inhibitors and $\left[{ }^{3} \mathrm{H}\right]$ puromycin were simultaneously added at the end of the transloctation period. In Assay B the required inhibitors were added at the end of the translocation period and incubation continued for 3 minutes prior to the final reaction with $\left[{ }^{3} \mathrm{H}\right]$ puromycin. Assay B gives in some cases higher values for inhibition of the puromycin reaction than the Assay A. Thus some inhibitors require a certain time to interact with the polysomes and therefore give lower values of inhibition 
Fig. 5. $\left[{ }^{3} \mathrm{H}\right]$ Anisomycin binding to yeast polysomes

SCATCHARD plot of the data for $\left[{ }^{3} \mathrm{H}\right]$ anisomycin binding to polysomes from yeast treated in vivo with cycloheximide. Data were obtained from an ultracentrifugation assay $(140,000 \times g$ during 2 hours) carried out at $0^{\circ} \mathrm{C}$ as previously described ${ }^{18}$, under the following ionic conditions: $50 \mathrm{~mm}$ Tris- $\mathrm{HCl}$ buffer, $\mathrm{pH} 7.4,30 \mathrm{~mm}$ $\mathrm{MgCl}_{2}$ and $100 \mathrm{~mm} \mathrm{KCl}$. Polysome concentration was $3 \mu \mathrm{M}$ for an $\left[{ }^{3} \mathrm{H}\right]$ anisomycin concentration range of $1 \sim 3 \mu \mathrm{M}$ and $5 \mu \mathrm{M}$ for an $\left[{ }^{3} \mathrm{H}\right]$ anisomycin concentration range of $3 \sim 30 \mu \mathrm{M}$. Incubation volumes were 80 and $60 \mu \mathrm{l}$ respectively, and samples (20 and $10 \mu 1$ respectively) were taken before and after sedimentation of the polysomes to estimate radioactivity.

Polysomes with high affinity for $\left[{ }^{3} \mathrm{H}\right]$ anisomycin binding $(12 \%$ of the total polysomes as shown in the abscissa) are those with peptidyltRNA bound to the P-site ${ }^{18)}$. Polysomes with the lower affinity binding for $\left[{ }^{3} \mathrm{H}\right]$ anisomycin (76\% of the total polysomes as shown in the abscissa) are those peptidyl-tRNA bound to the A-site ${ }^{19)}$

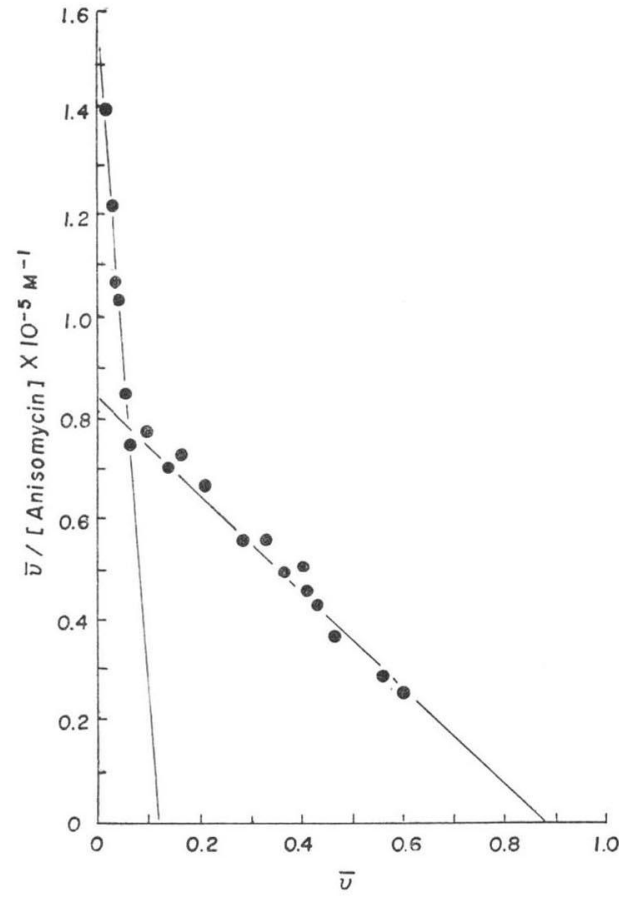

when added simultaneously with puromycin (Assay B).

Anisomycin, sparsomycin, blasticidin S, trichodermin, trichodermol, trichothecin and fusarenon $\mathrm{X}$ inhibit the puromycin reaction by polysomes, whereas diphtheria toxin, pederine, cycloheximide doxycyline $(0.2 \mathrm{~mm})$ and aurintricarboxylic acid $(0.1 \mathrm{~mm})$ (results not shown) do not affect peptide bond formation. Cryptopleurine, at rather high concentrations, has a certain inhibitory effect in the reaction.

Some antibiotics interact with the ribosome following slower kinetics than the puromycin reaction. Therefore when added to the system at the same time as $\left[{ }^{3} \mathrm{H}\right]$ puromycin (Table 3, Assay A) their effect is much smaller than in the case of adding them prior to $\left[{ }^{3} \mathrm{H}\right]$ puromycin (Table 3, Assay B). The most striking differences between the results on Assay A and B were obtained with blasticidin $\mathrm{S}$, fusarenon $\mathrm{X}$, trichothecin and trichodermin. This shows the importance of adding the inhibitors prior to puromycin when assaying their effect in peptide bond formation.

\section{Effect of Inhibitors on Translocation}

In order to test the effect of inhibitors in the translocation step, polysomes were preincubated at $30^{\circ} \mathrm{C}$ with GTP and the supernatant fraction in the presence of the required inhibitor prior to the addition of $\left[{ }^{3} \mathrm{H}\right]$ puromycin (Table 4). Only $44 \%$ of the peptidyl- $\left[{ }^{3} \mathrm{H}\right]$ puromycin synthesised in the control is formed in the absence of the supernatant. Therefore $56 \%$ of the reaction is due to peptidyl-tRNA initially bound to the acceptor site and trans-

located enzymically. Hence, specific inhibitors of translocation cannot inhibit over $56 \%$ the total extent of peptidyl- $\left[{ }^{3} \mathrm{H}\right]$ puromycin formation in the assay. As it is shown in Table 4 diphtheria toxin, pederine, cycloheximide and cryptopleurine are very effective inhibitors of translocation. Doxycycline $(0.2 \mathrm{~mm})$ and aurintricarboxylic acid $(0.1 \mathrm{~mm})$ have no significant effect on this step (not shown). 
Table 3. Peptidyl- $\left[{ }^{3} \mathrm{H}\right]$ puromycin formation by yeast polysomes. Effect of protein synthesis inhibitors

\begin{tabular}{|c|c|c|c|}
\hline \multirow{2}{*}{ System } & \multirow{2}{*}{$\begin{array}{l}\text { Inhibitor } \\
\text { (mM conc.) }\end{array}$} & \multicolumn{2}{|c|}{$\begin{array}{c}\text { Peptide bond formation } \\
\% \text { Control }\end{array}$} \\
\hline & & Assay A & Assay B \\
\hline Complete & & 100 & 100 \\
\hline+ Anisomycin & 0.1 & 1 & 一 \\
\hline+ Tenuazonic acid & 1 & 99 & 102 \\
\hline Sesquiterpene antibiotics: & & & \\
\hline+ Trichodermin & 0.4 & 25 & 1 \\
\hline+ Trichodermol & 0.4 & 26 & 25 \\
\hline+ Trichothecin & 0.2 & 49 & 1 \\
\hline+ Fusarenon $\mathrm{X}$ & 0.2 & 85 & 11 \\
\hline+ Sparsomycin & 0.01 & 1 & - \\
\hline+ Blasticidin S & 1 & 89 & 27 \\
\hline + Diphtheria toxin* & 0.01 & 100 & - \\
\hline+ Pederine & 0.04 & 104 & - \\
\hline+ Cycloheximide & 1 & 93 & 102 \\
\hline + Cryptopleurine & 0.3 & - & 49 \\
\hline + Cryptopleurine & 0.01 & 92 & 96 \\
\hline
\end{tabular}

Total reaction mixtures contained in a final volume of $50 \mu \mathrm{l}, 2.3 \mathrm{~A}_{260}$ units of polysomes with $4 \mu \mathrm{M}\left[{ }^{3} \mathrm{H}\right]$ puromycin $(3.7 \mathrm{Ci} / \mathrm{mmol})$ for 1 minute at $30^{\circ} \mathrm{C}$ under the following ionic conditions: $50 \mu \mathrm{M}$ Tris- $\mathrm{HCl}$ buffer, $\mathrm{pH} 7.4,12.5 \mathrm{~mm} \mathrm{MgCl}_{2}, 80 \mathrm{~mm}$ $\mathrm{KCl}, 0.5 \mathrm{~mm}$ GTP and $5 \mu \mathrm{l}$ of crude supernatant fraction. Specific conditions for Assays A and B were as follows: In Assay A polysomes were incubated for 7 minutes in the presence of GTP and the supernatant fraction to translocate the peptidyl-tRNA initially bound to the acceptor site; the required inhibitor and $\left[{ }^{3} \mathrm{H}\right]$ puromycin were then added and the incubation continued for 1 minute more. The Assay B is similar to Assay A but the required inhibitors were added to the incubation mixture at the end of the translocation period and $\left[{ }^{3} \mathrm{H}\right]$ puromycin was added $3 \mathrm{~min}$ later. In all cases the temperature of incubation was $30^{\circ} \mathrm{C}$ and reaction was stopped with $1 \mathrm{ml}$ of $10 \%$ cold trichloroacetic acid. Blanks, obtained by adding the $10 \%$ trichloroacetic acid prior to $\left[{ }^{3} \mathrm{H}\right]$ puromycin, were subtracted in all cases. 1.55 pmoles of peptidyl- $\left[{ }^{3} \mathrm{H}\right]$ puromycin were formed in the controls.

* $0.01 \mathrm{~mm}$ NAD was present in the system when the effect of diphtheria toxin was assayed.

Table 4 .

\begin{tabular}{|c|c|c|c|c|}
\hline System & $\begin{array}{l}\mathrm{mm} \text { conc } \\
\text { inhibitor }\end{array}$ & $\begin{array}{c}\text { Peptidyl- }\left[{ }^{3} \mathrm{H}\right] \\
\text { puromycin } \\
\text { formation } \\
\% \text { Control }\end{array}$ & $\begin{array}{c}\text { Total } \\
\text { translocation } \\
\% \text { total reaction }\end{array}$ & $\begin{array}{l}\text { Translocation } \\
\% \text { Control }\end{array}$ \\
\hline Minus supernatant & - & 44 & 0 & 0 \\
\hline Complete & - & 100 & 56 & 100 \\
\hline+ Diphtheria toxin* & 0.01 & 44 & 0 & 0 \\
\hline+ Pederine & 0.04 & 45 & 1 & 2 \\
\hline+ Cycloheximide & 1 & 48 & 4 & 7 \\
\hline + Cryptopleurine & 0.01 & 45 & 1 & 2 \\
\hline
\end{tabular}

Total reaction mixtures were as indicated in Table 3 , but polysomes were incubated for 7 minutes at $30^{\circ} \mathrm{C}$ in the presence of GTP, the supernatant fraction and the required inhibitor. $\left[{ }^{3} \mathrm{H}\right] \mathrm{Puromycin}$ was then added and the incubation continued for 1 minute more. 1.54 pmoles of peptidyl-[ $\left.{ }^{3} \mathrm{H}\right]$ puromycin were formed in the complete system.

* $0.01 \mathrm{~mm}$ NAD was present in the system when the effect of diphtheria toxin was assayed. 


\section{Discussion}

Yeast polysomes are fairly stable and can be prepared free from ribosomes by sedimentation through $60 \%$ sucrose layers. These purified polysomes are quite active for amino acid incorporation (Fig. 1) but do not appear to initiate nor terminate the polypeptide chain ${ }^{3)}$. Therefore, this is a natural system, as shown with $E$. coli polysomes, for studying the elongation cycle of translation $^{21)}$. The amount of peptidyl puromycin formed depends on the $\mathrm{K}^{+}$concentration (Fig. 2) and around $60 \%$ of the endogenous peptidyl-tRNA reacts with $\left[{ }^{3} \mathrm{H}\right]$ puromycin under our standard experimental conditions (Fig. 3). About $80 \%$ of the peptidyl-tRNA (Fig.5) is initially bound to the A-site and the system in suitable for studying peptide bond formation and translocation. In polysomal systems from eukaryotes optimal peptidyl- $\left[{ }^{3} \mathrm{H}\right]$ puromycin synthesis appears to take place at very high $\mathrm{K}^{+}$concentrations $(0.8 \% \mathrm{KCl})(\mathrm{Fig} .2)^{4,16)}$. However the results obtained in the puromycin reaction at such high $\mathrm{K}^{+}$concentration might induce errors of interpretation. Thus the antibiotic cycloheximide, which has repeatedly been reported not to inhibit peptide bond formation, blocks the puromycin reaction with polysomes at $0.8 \mathrm{M}$ $\mathrm{K}^{+}(\text {Table } 2)^{22)}$. These results suggest that at high concentrations of monovalent ion there is a drastic change in the ribosomal structure which might lead to non-enzymic translocation of peptidyl-tRNA from the A- to the P-site at least on the terminal end of the substrate on the $60 \mathrm{~S}$ ribosome subunit. Another possibility is that peptidyl-tRNA bound to the A-site is released at high $\mathrm{K}^{+}$concentration and subsequently bound to the P-site, as has been suggested in another system ${ }^{23)}$. Therefore peptidyl $-\left[{ }^{3} \mathrm{H}\right]$ puromycin formation by eukaryotic polysomes at $0.8 \mathrm{M} \mathrm{K}^{+}$is not a suitable system to elucidate the specific step blocked by inhibitors of protein synthesis, although the assay has been used for this purpose in some cases ${ }^{22}$. Therefore, assays for peptidyl $-\left[{ }^{3} \mathrm{H}\right]$ puromycin formation were carried out in this work under ionic conditions $(12.5 \mathrm{~mm}$ $\mathrm{MgCl}_{2}$ and $80 \mathrm{mM} \mathrm{KCl}$ ) which were optimal for amino acid incorporation and for enzymic translocation but do not favour non-enzymic translocation.

Sesquiterpene antibiotics of the trichodermin group act on the peptidyl transferase centre of the larger subunit of eukaryotic ribosomes ${ }^{7,11,24)}$. Trichodermin, trichodermol, trichothecin and fusarenon $\mathrm{X}$ effectively inhibit peptide bond formation in the puromycin reaction (Table 3) and the fragment reaction assay ${ }^{7)}$. Trichodermin and trichodermol are rather poor inhibitors of elongation in our polysomal system (Table 1) suggesting that their affinity for polysomes actively engaged in peptide elongation is rather low. However these antibiotics can inhibit polypeptide elongation in intact cells ${ }^{25}$ probably by interacting with the $60 \mathrm{~S}$ ribosome subunit prior to the formation of the polysomes. Hence trichodermin, trichodermol, tricothecin and fusarenon $\mathrm{X}$, inhibit elongation and termination of the polypeptide chain by blocking the peptidyl transferase ${ }^{25,28)}$. Fusarenon $\mathrm{X}$ also causes in vivo polysome breakdown suggesting an effect on initiation ${ }^{27,28)}$. Inhibition of both initiation and elongation by fusarenon $\mathrm{X}$ can be explained by a single interaction of the antibiotic with the $60 \mathrm{~S}$ subunit blocking the attachment of the 3'-terminal end of fMet-tRNA and peptidyl-tRNA.

Anisomycin and sparsomycin are very effective inhibitors of peptide bond formation as previously observed in other systems ${ }^{1,14,15}$; reviews $)$ Blasticidin $\mathrm{S}$ was the most effective inhibitor of peptide bond formation of the antibiotics studied belonging to the 4-amino-hexose pyrimidine nucleoside group. The antibiotics amicetin and actinobolin had only a limited effect on the elongation cycle.

Translocation in our polysomal system is totally blocked by diphtheria toxin in the presence of NAD $(0.01 \mathrm{~mm})$ (Table 4). Pederine is also a very active inhibitor of translocation in agreement with previous results in model systems ${ }^{8,29)}$.

Report on the mode of action of cycloheximide on eukaryotic protein synthesis are conflicting ${ }^{1 ; \text { review }) . ~ T r a n s l o c a t i o n ~ i s ~ g e n e r a l l y ~ a c c e p t e d ~ a s ~ t h e ~ t a r g e t ~ f o r ~ c y c l o h e x i m i d e ~ a c t i o n ~ i n ~}$ elongation ${ }^{19,20)}$; this is confirmed in this work (Table 3 ). Although cycloheximide inhibits the puromycin reaction with polysomes at high $\mathrm{K}^{+}$concentration (ref. 22 and Table 2), this is not due to a direct effect of the antibiotic on the reaction as it is shown in this work that the 
extent of peptidyl- $\left[{ }^{3} \mathrm{H}\right]$ puromycin formation in the presence of cycloheximide is independent of the $\mathrm{K}^{+}$concentration (Table 2). Moreover inhibitory effect of this antibiotic on the elongation cycle (Table 1) corresponds well with its effect in blocking the translocation reaction (Table 4).

Cryptopleurine belongs, with tylophorine and tylocrebrine, to the Tylophora alkaloids, all of which have a closely related mechanism of action'; review). Cryptopleurine ${ }^{31)}$ and tylocrebrine ${ }^{30)}$ inhibit translocation in model systems. However PestKa et al. ${ }^{22)}$ observed an inhibitory effect of cryptopleurine in peptidyl- $\left[{ }^{3} \mathrm{H}\right]$ puromycin formation by polysomes at $0.8 \mathrm{M} \mathrm{KCl}$. As shown in Table $4,10^{-5} \mathrm{M}$ cryptopleurine almost completely inhibits translocation whereas a much higher concentration of the compound is required to affect peptide bond formation (Table 3). Cryptopleurine inhibition of translocation parallels its inhibitory effect on polypeptide elongation (Table 1). Hence we conclude that translocation is the main target for cryptopleurine action.

\section{Acknowledgements}

We thank Miss A. Martin for expert technical assistance. This work has been supported by Grants from "Fondo Nacional para el desarrollo de la Investigacion Cientifica and Lilly Indiana of Spain". M. B. was the holder of a fellowship of "Plan de Formacion de Personal Investigador."

\section{References}

1) VAZquez, D.: Inhibitors of protein synthesis. FEBS Letters 40 supplement: S63 S84, 1974

2) Hutchison, H. T.; L. H. Hartwell \& C. S. McLaughlin: Temperature sensitive yeast mutant defective in ribonucleic acid production. J. Bact. 99: 807 814, 1969

3) Jimenez, A.; D. J. Tipper \& J. Davies: Mode of action of thiolutin, an inhibitor of macromolecular synthesis in Saccharomyces cerevisiae. Antimicr. Agents \& Chemoth. 3: 729 738, 1973

4) Pestika, S.; R. Goorha, H. Rosenfeld, C. Neurath \& H. Hintikka: Studies on transfer ribonucleic acid-ribosome complexes. XX. Peptidyl-puromycin synthesis in mammalian polyribosome. J. Biol. Chem. 247: 4258 4263, 1972

5) Barbacid, M. \& D. VazQuez: Preparation of pure ${ }^{3} \mathrm{H}$-anisomycin by tritium exchange labeling. Anal. Biochem. 56: 16 25, 1973

6) Barbacid, M. \& D. Vazquez: ${ }^{3} \mathrm{H}$-Anisomycin binding to eukaryotic ribosomes. J. Mol. Biol. 84: $603 \sim 623,1974$

7) Carrasco, L.; M. Barbacid \& D. Vazquez: The trichodermin group of antibiotics, inhibitors of peptide bond formation by eukaryotic ribosomes. Biochim. Biophys. Acta 312: 268 276, 1973

8) Carrasco, L. \& D. Vazquez: Survey of inhibitors in different steps of protein synthesis by mammalian ribosomes. J. Antibiotics 25: 732 737, 1972

9) Carrasco, L. \& D. Vazquez: Differences in eukaryotic ribosomes detected by the selective action of an antibiotic. Biochim. Biophys. Acta 319: 209 215, 1973

10) Battaner, E. \& D. Vazquez: Inhibitors of protein synthesis by ribosomes of the 80 S type. Biochim. Biophys. Acta 254: 316 330, 1971

11) BARbacid, M. \& D. VAzQuez: $\left\{\mathrm{G}^{3} \mathrm{H}\right\}$ Gougerotin binding to ribosomes. Hetereogeneity of eukaryotic ribosomes. Europ. J. Biochem. 44: 445 453, 1974

12) GregG, R.E. \& R. L. Heintz: The inhibition of eukaryotic aminoacyl transferase I by chartreusin. Arch. Biochem. Biophys. 152: 451 456, 1972

13) Bermek, E.; W. Kramer, H. Monkemeyer \& H. Matthaei: Mechanism in protein synthesis. XII. Sites of action of showdomycin in a cell free polyphenylalanine synthesizing system from human lymphatic tissue: Ribosomes and elongation factor IF II. Biochem. Biophys. Res. Commun. 40: $1311 \sim 1318,1970$

14) Pestk A, S.: Inhibitors of ribosome functions. Ann. Rev. Microbiol. 25: 487 562, 1971

15) Gale, E. F.; E. Cundliffe, P. E. Reynolds, M. H. Richmond \& M. J. Waring: The Molecular Basis of Antibiotic Action. pp 278 379, John Wiley \& Sons (London) 1972

16) Baliga, B. S.; M. G. Schechtman, R. D. Nolan \& H. N. Munro: Influence of temperature and monovalent cations on reactivity of the donor and acceptor sites on mammalian ribosomes. Biochim. Biophys. Acta 312: 349 357, 1973

17) Blobel, G. \& D. Sabatini: Dissociation of mammalian polyribosomes into subunits by puromycin. Proc. Natl. Acad. Sci. U.S. 68: 390 394, 1971. 
18) Barbacid, M. \& D. Vazquez: Ribosome changes during translation. J. Mol. Biol. (in press), 1975

19) Baliga, B.S.; S. A. Cohen \& H. N. Munro: Effect of cycloheximide on the reaction of puromycin with polysome-bound peptidyl-tRNA. FEBS Letters 8: 249 252, 1970

20) Obrig, T. G.; W. J. Culp, W. L. McKeehan \& B. Hardesty: The mechanism by which cycloheximide and related glutarimide antibiotics inhibit peptide synthesis on reticulocyte ribosomes. J. Biol. Chem. 246: 174 181, 1971

21) Tai, P. C.; J. B. Wallace, E. L. Herzog \& B. D. Davis: Properties of initiation-free polysomes of E. coli. Biochemistry 12: 609 615, 1973

22) Pestka, S.; H. Rosenfeld, R. Harris \& H. Hintikka: Studies on transfer ribonucleic acidribosome complexes. XXI. Effect of antibiotics on peptidyl-puromycin synthesis by mammalian polyribosomes. J. Biol. Chem. 247: 6895 6900, 1972

23) Monro, R.E.: Protein synthesis: Uncoupling of polymerization from template control. Nature 223: $903 \sim 905,1969$

24) Schindler, D; P. Grant \& J. Davies: Trichodermin resistance mutation affecting eukaryotic ribosomes. Nature 248: 535 537, 1974

25) Cundliffe, E.; M. Cannon \& J. Davies: Mechanism of inhibition of eukaryotic protein synthesis by trichothecene fungal toxins. Proc. Natl. Acad. Sci. U.S. 71: 30 34, 1974

26) Wei, C. \& C. S. McLaughlin: Structure-function relationship in the 12, 13-epoxytrichothecenes. Novel inhibitor of protein synthesis. Biochem. Biophys. Res. Commun. 57: 838 844, 1974

27) Ohtsubo, K.; P. Kaden \& C. Mittermayer: Polyribosomal breakdown in mouse fibroblasts (L-cells) by fusarenon $\mathrm{X}$, a toxic principle isolated from Fusarium nivale. Biochim. Biophys. Acta 287: 520 525, 1972

28) Ueno, Y.; M. Nakajima, K. Sakai, K. Ishit, N. Sato \& N. Shimada: Comparative toxicology of trichothecin mycotoxin: Inhibition of protein synthesis in animal cells. J. Biochem. (Tokyo) 74: $285 \sim 296,1973$

29) Jacobs-Lorena, M.; A. Brega \& C. Baglioni: Inhibition of protein synthesis in reticulocytes by antibiotics. V. Mechanism of action of pederine, an inhibitor of initiation and elongation. Biochim. Biophys. Acta 240: 263 272, 1971

30) Huang, M. \& A. P. Grollman: Mode of action of tylocrebrine: Effects on protein and nucleic acid synthesis. Mol. Pharmacol. 8: 538 550, 1972

31) Carrasco, L.; C. Fernandez-Puentes \& D. Vazquez: Antibiotics and compounds affecting translation by eukaryotic ribosomes. Mol. Cel. Biochem. 1975, in press 